ISSN 0258-7122 (Print), 2408-8293 (Online)

Bangladesh J. Agril. Res. 42(1): 43-52, March 2017

\title{
RESPONSE OF CAPSICUM TO BORON AND ZINC APPLICATION IN TERRACE SOILS OF GAZIPUR, BANGLADESH
}

\author{
R. AHMED ${ }^{1}$, M. A. SIDDIKY ${ }^{2}$, M. R. KARIM ${ }^{3}$ \\ M. A. QUDDUS ${ }^{4}$ AND S. AHMED 5
}

\begin{abstract}
A field experiment was conducted at vegetables research field of Horticulture Research Centre, Gazipur in terrace soils under Madhupur Tract (AEZ 28) during rabi seasons of 2009-10, 2010-11 and 2011-12 to determine the optimum dose of boron and zinc for yield maximization of capsicum. There were sixteen treatment combinations comprising four levels each of $\mathrm{B}\left(0,1,2\right.$ and $\left.3 \mathrm{~kg} \mathrm{ha}^{-1}\right)$ and $\mathrm{Zn}\left(0,2,3\right.$ and $\left.4 \mathrm{~kg} \mathrm{ha}^{-1}\right)$ along with blanket dose of $\mathrm{N}_{150} \mathrm{P}_{65} \mathrm{~K}_{120} \mathrm{~S}_{20} \mathrm{~kg} \mathrm{ha}^{-1}$ including cow dung $10 \mathrm{t} \mathrm{ha}^{-1}$ were used. The experiment was laid out in RCBD factorial with three replications. Results revealed that maximum mean number of fruits per plant $(11.1)$, the highest fruit length $(9.29 \mathrm{~cm})$ and diameter $(7.34$ $\mathrm{cm})$, maximum individual weight of fruits $(122 \mathrm{~g})$ were recorded from the combination treatment of $\mathrm{B}_{2.0} \mathrm{Zn}_{3.0}$ and the highest mean yield $\left(31.8 \mathrm{t} \mathrm{ha}^{-1}\right)$ was also recorded from the same treatment. The $84.8 \%$ yield increase over control $\left(\mathrm{B}_{0} \mathrm{Zn}_{0}\right)$ due to combined application of $\mathrm{B}_{2.0} \mathrm{Zn}_{3.0} \mathrm{~kg} \mathrm{ha}^{-1}$. The combined application of zinc and boron were observed superior to their single application. Therefore, the combination of $\mathrm{B}_{2.0} \mathrm{Zn}_{3.0}$ treatment may be considered as suitable dose for capsicum cultivation in terrace soils of Bangladesh.
\end{abstract}

Keywords: Capsicum, boron and zinc, terrace soils, yield.

\section{Introduction}

Sweet capsicum (Capsicum annum cv. California wonder) is one of the most important high valued vegetable crop grown extensively throughout the world especially in the temperate countries (Manchanda and Singh, 1987). Capsicum belonging to the family Solanaceae is very sensitive to soil nutrients and environmental factors (Bhatt et al., 1999). The optimum temperature for capsicum ranged from $16^{0}$ to $26^{\circ} \mathrm{C}$ (Bakker, 1989). Capsicum may be eaten as cooked or raw as well as sliced in salads. The leaves are also consumed as salads, soups or eaten with rice. It is a good source of medicinal preparation for black vomit, tonic for gout and paralysis (Knott and Deanon, 1967). It contains 1.29 $\mathrm{mg}$ protein, $11 \mathrm{mg} \mathrm{Ca}, 870 \mathrm{I}$. U. vitamin A, $175 \mathrm{mg}$ ascorbic acid, $0.06 \mathrm{mg}$ thiamine, $0.03 \mathrm{mg}$ riboflavin and $0.55 \mathrm{mg}$ niacin per $100 \mathrm{~g}$ edible fruit. The sweet pepper is the second most important after tomato in the world (AVRDC, 1989).

\footnotetext{
${ }^{1 \& 3}$ Scientific Officer, Horticulture Research Centre, Bangladesh Agricultural Research Institute (BARI), Gazipur, ${ }^{2 \& 4}$ Senior Scientific Officer, Horticulture Research Centre, BARI, Gazipur, ${ }^{5}$ Scientific Officer, Biotechnology Division, BARI, Gazipur, Bangladesh.
} 
But it is a minor vegetable in Bangladesh and production statistics are not available (Hasanuzzaman, 1999). Small scale cultivation is found in peri-urban areas (Savar, Kashimpur, Bogra, Chittagong) for the supply to some city markets in Bangladesh. It has good demand to some big hotels in the city to feed the foreigners residing in Bangladesh. The crop has achieved high export potentiality. Considering its high nutritive value, export potentiality and low production some attempts has been taken to successful cultivation in Bangladesh. But some constraints which include nutrients deficiency, flower dropping, and poor fruit set, susceptibility to viral diseases etc. are affects the good yield of capsicum. For sustainable crop yields balanced fertilizations with all the nutrients (major and trace) that are deficient in soils need to be taken into account. Zinc and B deficiency is widespread in the country; much observed in wetland rice soils and light textured soils (Jahiruddin et al., 1992; Islam et al., 1997). Zinc is involved in auxin formation; activation of dehydrogenase enzymes; stabilization of ribosomal fractions (Obata et al., 1999). Boron is essential for reproductive growth, especially flowering and fruit, and seed set is more sensitive to B deficiency than vegetative growth (Dear and Lipsett, 1987). Boron influence the absorption of $\mathrm{N}, \mathrm{P}, \mathrm{K}$ and its deficiency changes the equilibrium of optimum of those three macronutrients (Raj, 1985). Farmers do not have any recommended doses of fertilizers (micronutrients) for boosting fruit yield of capsicum. As a result farmers are not getting desired and expected yield of fruits. Hence, the experiment was undertaken to find out the optimum dose of boron and zinc for maximizing the yield of capsicum in Terrace soils of Bangladesh.

\section{Materials and Method}

The field experiment was carried out at the vegetable research field of Horticulture Research Centre, BARI, Gazipur during Rabi season of 2009-10, 2010-11 and 2011-12 to find out the optimum dose of boron and zinc for yield maximization of capsicum. Experimental site-Gazipur $\left(24^{\circ} 0^{\prime} 13^{\prime \prime} \mathrm{N}\right.$ latitude and $90^{\circ} 25^{\prime} 0^{\prime \prime}$ E longitude) lies at an elevation of $8.4 \mathrm{~m}$ above the sea level. The terrace soil of Gazipur belongs to Chhiata series (Soil taxonomy: Udic Rhodustalf) under the agro ecological zone Madhupur Tract and texture is clay loam. There were 16 treatment combinations comprising four levels each of $\mathrm{B}(0,1$, 2 and $\left.3 \mathrm{~kg} \mathrm{ha}^{-1}\right)$ and $\mathrm{Zn}\left(0,2,3\right.$ and $\left.4 \mathrm{~kg} \mathrm{ha}^{-1}\right)$ along with a blanket dose of $\mathrm{N}_{150} \mathrm{P}_{65} \mathrm{~K}_{120} \mathrm{~S}_{20} \mathrm{~kg} \mathrm{ha}^{-1}$ and $10 \mathrm{t} \mathrm{ha}^{-1}$ cow dung was used. The treatments were arranged viz. $\mathrm{T}_{1}=\mathrm{B}_{0} \mathrm{Zn}_{0} ; \mathrm{T}_{2}=\mathrm{B}_{0} \mathrm{Zn}_{2} ; \mathrm{T}_{3}=\mathrm{B}_{0} \mathrm{Zn}_{3} ; \mathrm{T}_{4}=\mathrm{B}_{0} \mathrm{Zn}_{4} ; \mathrm{T}_{5}=\mathrm{B}_{1} \mathrm{Zn}_{0} ; \mathrm{T}_{6}=$ $\mathrm{B}_{1} \mathrm{Zn}_{2} ; \mathrm{T}_{7}=\mathrm{B}_{1} \mathrm{Zn}_{3} ; \mathrm{T}_{8}=\mathrm{B}_{1} \mathrm{Zn}_{4} ; \mathrm{T}_{9}=\mathrm{B}_{2} \mathrm{Zn}_{0} ; \mathrm{T}_{10}=\mathrm{B}_{2} \mathrm{Zn}_{2} ; \mathrm{T}_{11}=\mathrm{B}_{2} \mathrm{Zn}_{3} ; \mathrm{T}_{12}=\mathrm{B}_{2} \mathrm{Zn}_{4} ;$ $\mathrm{T}_{13}=\mathrm{B}_{3} \mathrm{Zn}_{0} ; \mathrm{T}_{14}=\mathrm{B}_{3} \mathrm{Zn}_{2} ; \quad \mathrm{T}_{15}=\mathrm{B}_{3} \mathrm{Zn}_{3} ;$ and $\mathrm{T}_{16}=\mathrm{B}_{3} \mathrm{Zn}_{4}$. Before setting the experiments, initial soil samples were collected from the experimental field from $0-15 \mathrm{~cm}$ depth and the collected samples were analyzed for chemical properties using standard procedures in the laboratory (Table 1). The land was prepared 
thoroughly by a tractor driven siezel and rotavator. The experiment was laid out in RCBD factorial with three replications. The unit plot size was $2 \mathrm{~m} \times 1 \mathrm{~m}$ along with spacing of $50 \mathrm{~cm} \times 40 \mathrm{~cm}$. Nitrogen, $\mathrm{P}, \mathrm{K}$ and $\mathrm{S}$ were supplied as urea, TSP, MoP and gypsum fertilizer, respectively. All P, K, S fertilizer including cow dung were applied and mixed up well at the time of final land preparation. Boron and zinc were applied as boric acid and zinc sulphate in the respective treatments plot during final bed preparation. The 25 days old capsicum (var. California wonder) seedlings were transplanted at three consecutive years on 18 December 2009, 19 December 2010 and 18 December 2011. Urea was applied in three equal splits at 30, 45 and 60 days after transplanting. Poly tunnels were used for minimizing the night temperature. Intercultural practices like weeding, irrigation, spraying pesticides etc. were done in time. Data on plant height, number of fruits per plant, length, diameter and individual fruit weight were recorded from five randomly selected plants. All the necessary data on different parameters were computed for statistical analysis and adjusted with DMRT at 5\% level of significance.

Table 1. Chemical properties of the initial soil of the experimental field

\begin{tabular}{|c|c|c|c|c|c|c|c|c|c|c|c|c|c|}
\hline \multirow{2}{*}{ Location } & \multirow{2}{*}{$\mathrm{pH}$} & \multirow{2}{*}{$\mathrm{OM}$} & $\mathrm{Ca}$ & $\mathrm{Mg}$ & $\mathrm{K}$ & \multirow{2}{*}{$\begin{array}{l}\text { Total } \\
\text { N \% }\end{array}$} & $\mathrm{P}$ & $\mathrm{S}$ & $\mathrm{B}$ & $\mathrm{Cu}$ & $\mathrm{Fe}$ & $\mathrm{Mn}$ & $\mathrm{Zn}$ \\
\hline & & & & leq/10 & & & \multicolumn{7}{|c|}{$\mu \mathrm{g} / \mathrm{g}$} \\
\hline Joydebpur & 6.5 & 0.91 & 1.5 & 0.7 & 0.18 & 0.048 & 10 & 12 & 0.1 & 1.0 & 140 & 4.2 & 1.0 \\
\hline $\begin{array}{l}\text { ritical } \\
\text { vel }\end{array}$ & - & - & 2.0 & 0.8 & 0.20 & 0.12 & 14 & 14 & 0.2 & 1.0 & 10 & 5.0 & 2.0 \\
\hline
\end{tabular}

\section{Results and Discussion}

\section{Effect of Boron}

Different levels of boron played a significant role on yield and yield contributing characters of capsicum (Tables $2 \& 3$ ). Results revealed that all yield contributing characters were showed increasing trend due to application of $2 \mathrm{~kg}$ $\mathrm{B} \mathrm{ha} \mathrm{a}^{-1}$ over the other treatments. But over dose of $3 \mathrm{~kg} \mathrm{~B} \mathrm{ha}^{-1}$ or lower dose which depressed the all yield attributes. The mean (mean of three years) number of fruits per plant ranged from 5.94 to 9.80 . The maximum number of fruits per plant was recorded from the treatment B level $2.0 \mathrm{~kg} \mathrm{ha}^{-1}$ which was statistically significant with others treatment during 2010, 2011 and 2012. The average fruit length and diameter were varied from 5.90 to $8.17 \mathrm{~cm}$ and 4.89 to $6.59 \mathrm{~cm}$, respectively. The highest fruit length and diameter were recorded from the treatment $2 \mathrm{~kg} \mathrm{~B} \mathrm{ha}^{-1}$ which was significantly different with the other treatment but statistically identical to the treatment $\mathrm{B}_{1}$ and $\mathrm{B}_{3}$ in all the years. The mean individual fruit weight ranged from 79.5 to $110 \mathrm{~g}$, the highest being noted at $\mathrm{B}$ application of $2 \mathrm{~kg} \mathrm{ha}^{-1}$. Application of $\mathrm{B}$ above or less than $2 \mathrm{~kg} \mathrm{ha}^{-1}$ led to 
reduce yield of capsicum. All yield attributes were shown lowest due to control $\left(\mathrm{B}_{0}\right)$ treatment (Tables $2 \& 3$ ). Chilli and tomato yield was increased with boron application (Govindan, 1952). Schon (1990) observed that application of $1.12 \mathrm{~kg}$ $\mathrm{B} \mathrm{ha}^{-1}$ significantly increased the yield and yield component of plant.

Table 2. Main effect of boron on yield contributing characters of capsicum

\begin{tabular}{l|c|c|c|c|c|c|c|c|c|c|c|c}
\hline \multirow{2}{*}{ Treatment } & \multicolumn{4}{|c|}{ Fruits plant $^{-1}$} & \multicolumn{4}{c|}{ Fruit length $(\mathrm{cm})$} & \multicolumn{4}{c}{ Fruit diameter $(\mathrm{cm})$} \\
\cline { 2 - 14 } & 2010 & 2011 & 2012 & mean & 2010 & 2011 & 2012 & mean & 2010 & 2011 & 2012 & mean \\
\hline $\mathrm{B}_{0}$ & $3.57 \mathrm{e}$ & $6.77 \mathrm{c}$ & $7.47 \mathrm{c}$ & 5.94 & $5.23 \mathrm{~b}$ & $6.23 \mathrm{~b}$ & $6.23 \mathrm{~b}$ & 5.90 & $4.60 \mathrm{~b}$ & $5.05 \mathrm{~b}$ & $5.03 \mathrm{~b}$ & 4.89 \\
$\mathrm{~B}_{1}$ & $5.75 \mathrm{~b}$ & $9.78 \mathrm{~b}$ & $10.48 \mathrm{~b}$ & 8.67 & $6.33 \mathrm{a}$ & $8.29 \mathrm{a}$ & $8.27 \mathrm{a}$ & 7.63 & $5.74 \mathrm{a}$ & $6.55 \mathrm{a}$ & $6.26 \mathrm{a}$ & 6.18 \\
$\mathrm{~B}_{2}$ & $7.33 \mathrm{a}$ & $10.7 \mathrm{a}$ & $11.36 \mathrm{a}$ & $\mathbf{9 . 8 0}$ & $6.74 \mathrm{a}$ & $8.92 \mathrm{a}$ & $8.84 \mathrm{a}$ & $\mathbf{8 . 1 7}$ & $6.23 \mathrm{a}$ & $6.92 \mathrm{a}$ & $6.61 \mathrm{a}$ & $\mathbf{6 . 5 9}$ \\
$\mathrm{B}_{3}$ & $5.75 \mathrm{~b}$ & $9.53 \mathrm{~b}$ & $10.23 \mathrm{~b}$ & 8.50 & $6.51 \mathrm{a}$ & $8.05 \mathrm{a}$ & $8.05 \mathrm{a}$ & 8.05 & $5.85 \mathrm{a}$ & $6.27 \mathrm{a}$ & $5.96 \mathrm{a}$ & 6.03 \\
$\mathrm{CV}(\%)$ & 6.91 & 11.2 & 10.55 & - & 5.76 & 9.75 & 9.85 & - & 4.56 & 8.45 & 8.65 & - \\
\hline
\end{tabular}

Values within the same column with a common letter do not differ significantly $(\mathrm{p}=0.05)$.

Table 3. Main effect of boron on yield and yield contributing characters of capsicum

\begin{tabular}{l|c|c|c|c|c|c|c|c}
\hline \multirow{2}{*}{ Treatment } & \multicolumn{5}{|c|}{ Weight fruit ${ }^{-1}(\mathrm{~g})$} & \multicolumn{4}{c}{${\text { Yield }\left(\mathrm{t} \mathrm{ha}^{-1}\right)}$} \\
\cline { 2 - 10 } & 2010 & 2011 & 2012 & mean & 2010 & 2011 & 2012 & mean \\
\hline $\mathrm{B}_{0}$ & $74.13 \mathrm{~b}$ & $82.5 \mathrm{~b}$ & $81.8 \mathrm{~b}$ & 79.5 & $8.18 \mathrm{~b}$ & $25.3 \mathrm{c}$ & $25.6 \mathrm{c}$ & 19.7 \\
$\mathrm{~B}_{1.0}$ & $79.55 \mathrm{~b}$ & $113 \mathrm{a}$ & $111.9 \mathrm{a}$ & 101 & $10.9 \mathrm{a}$ & $35.3 \mathrm{~b}$ & $35.3 \mathrm{~b}$ & 27.2 \\
$\mathrm{~B}_{2.0}$ & $87.08 \mathrm{a}$ & $122 \mathrm{a}$ & $120.2 \mathrm{a}$ & $\mathbf{1 1 0}$ & $11.5 \mathrm{a}$ & $38.0 \mathrm{a}$ & $37.8 \mathrm{a}$ & $\mathbf{2 9 . 1}$ \\
$\mathrm{B}_{3.0}$ & $78.57 \mathrm{~b}$ & $111 \mathrm{a}$ & $109.5 \mathrm{a}$ & 99.7 & $10.6 \mathrm{a}$ & $34.9 \mathrm{~b}$ & $34.9 \mathrm{~b}$ & 26.8 \\
$\mathrm{CV}(\%)$ & 7.13 & 10.5 & 10.25 & - & 7.39 & 12.7 & 11.85 & - \\
\hline
\end{tabular}

Values within the same column with a common letter do not differ significantly $(\mathrm{p}=0.05)$.

\section{Effect of Zinc}

During single application of different level of $\mathrm{Zn}$ were contributed significant role for showed positive performance on yield and yield component of capsicum during 2010, 2011 and 2012 (Tables $4 \&$ 5). The average numbers of fruits per plant were varied from 6.56 to 9.57 due to different levels of $\mathrm{Zn}$ application where the maximum number of fruits per plant (9.57) were found in $3 \mathrm{~kg} \mathrm{Zn} \mathrm{ha}{ }^{-1}$ and the lowest (6.56) was recorded from $\mathrm{Zn}_{0}$. The mean of fruit length and fruit diameter ranged from 6.22 to $8.32 \mathrm{~cm}$ and 4.96 to $6.61 \mathrm{~cm}$. The highest average length $(8.32 \mathrm{~cm})$ and diameter $(6.61 \mathrm{~cm})$, respectively were obtained from $3 \mathrm{~kg}$ $\mathrm{Zn} \mathrm{ha}{ }^{-1}$ followed by $4 \mathrm{~kg} \mathrm{Zn} \mathrm{ha-1}$ and $2 \mathrm{~kg} \mathrm{Zn} \mathrm{ha}^{-1}$ and the lowest was recorded from $\mathrm{Zn}_{0}$. The mean fruit weight varied from 84.7 to $109 \mathrm{~g}$. The highest fruit weight (109 g) was produced by $3 \mathrm{~kg} \mathrm{Zn} \mathrm{ha}^{-1}$ followed by $4 \mathrm{~kg}$ and $2 \mathrm{~kg} \mathrm{Zn} \mathrm{ha}^{-1}$. Hossain et al. (2010) reported that different level of $\mathrm{Zn}$ application with blanket dose of 20-20-20-5-1 $\mathrm{kg}$ NPKSB ha- significantly influenced the yield contributing characters of lentil. 
The lowest results of all yield contributing characters were observed in $\mathrm{Zn}_{0}$ plot. The highest average yield $\left(29.2 \mathrm{tha}^{-1}\right)$ was found by the application $3 \mathrm{~kg} \mathrm{Zn} \mathrm{ha}{ }^{-1}$ followed by $4 \mathrm{~kg}$ and $2 \mathrm{~kg} \mathrm{Zn}$ application ha- ${ }^{-1}$. Abdo (2001) reported that the increase in yield contributing characters and yield of plant with foliar spray of $\mathrm{Zn}$. The lowest yield $\left(21.4 \mathrm{t} \mathrm{ha}^{-1}\right)$ was recorded from $\mathrm{Zn}$ control treatment (Tables 4 \& 5). Results indicated that over dose or lower dose of $\mathrm{Zn}$ (Above or lower 3 $\mathrm{kg} \mathrm{Zn} \mathrm{ha-1)} \mathrm{application} \mathrm{might} \mathrm{be} \mathrm{suppressed} \mathrm{the} \mathrm{potential} \mathrm{yield} \mathrm{of} \mathrm{capsicum.}$

Table 4. Main effect of zinc on yield contributing characters of capsicum

\begin{tabular}{l|ccccc|c|c|c|c|c|c|c|c|c}
\hline \multirow{2}{*}{ Treatment } & \multicolumn{4}{|c|}{ Fruits plant $^{-1}$} & \multicolumn{4}{c|}{ Fruit length $(\mathrm{cm})$} & \multicolumn{4}{c}{ Fruit diameter $(\mathrm{cm})$} \\
\cline { 2 - 13 } & 2010 & 2011 & 2012 & mean & 2010 & 2011 & 2012 & mean & 2010 & 2011 & 2012 & mean \\
\hline $\mathrm{Zn}_{0}$ & $4.38 \mathrm{e}$ & $7.30 \mathrm{c}$ & $7.99 \mathrm{c}$ & 6.56 & $5.33 \mathrm{e}$ & $6.68 \mathrm{~b}$ & $6.64 \mathrm{~b}$ & 6.22 & $4.68 \mathrm{~b}$ & $5.24 \mathrm{~b}$ & $4.95 \mathrm{~b}$ & 4.96 \\
$\mathrm{Zn}_{2.0}$ & $5.45 \mathrm{~b}$ & $9.03 \mathrm{~b}$ & $9.73 \mathrm{~b}$ & 8.07 & $6.11 \mathrm{~b}$ & $7.76 \mathrm{ab}$ & $7.75 \mathrm{ab}$ & 7.21 & $5.61 \mathrm{a}$ & $6.17 \mathrm{a}$ & $5.89 \mathrm{a}$ & 5.89 \\
$\mathrm{Zn}_{3.0}$ & $6.55 \mathrm{a}$ & $10.73 \mathrm{a}$ & $11.44 \mathrm{a}$ & 9.57 & $6.97 \mathrm{a}$ & $9.03 \mathrm{a}$ & $8.96 \mathrm{a}$ & 8.32 & $6.18 \mathrm{a}$ & $6.97 \mathrm{a}$ & $6.67 \mathrm{a}$ & 6.61 \\
$\mathrm{Zn}_{4.0}$ & $6.02 \mathrm{ab}$ & $9.68 \mathrm{~b}$ & $10.38 \mathrm{~b}$ & 8.69 & $6.40 \mathrm{ab}$ & $8.03 \mathrm{ab}$ & $8.03 \mathrm{ab}$ & 7.49 & $5.95 \mathrm{a}$ & $6.39 \mathrm{a}$ & $6.37 \mathrm{a}$ & 6.24 \\
$\mathrm{CV}(\%)$ & 6.91 & 11.22 & 10.55 & - & 5.76 & 9.75 & 9.85 & - & 4.56 & 8.45 & 8.65 & - \\
\hline
\end{tabular}

Values within the same column with a common letter do not differ significantly $(\mathrm{p}=0.05)$.

Table 5. Main effect of zinc on yield and yield contributing characters of capsicum

\begin{tabular}{l|cccc|c|c|c|c|}
\hline \multirow{2}{*}{ Treatment } & \multicolumn{5}{|c|}{ Weight fruit ${ }^{-1}(\mathrm{~g})$} & \multicolumn{4}{c}{${\text { Yield }\left(\mathrm{t} \mathrm{ha}^{-1}\right)}$} \\
\cline { 2 - 9 } & 2010 & 2011 & 2012 & mean & 2010 & 2011 & 2012 & mean \\
\hline $\mathrm{Zn}_{0}$ & $75.85 \mathrm{~b}$ & $89.46 \mathrm{~b}$ & $88.75 \mathrm{~b}$ & 84.7 & $8.69 \mathrm{~b}$ & $27.68 \mathrm{c}$ & $27.93 \mathrm{c}$ & 21.4 \\
$\mathrm{Zn}_{2.0}$ & $79.26 \mathrm{ab}$ & $106.0 \mathrm{ab}$ & $104.3 \mathrm{ab}$ & 96.5 & $10.39 \mathrm{ab}$ & $35.28 \mathrm{~b}$ & $33.24 \mathrm{~b}$ & 26.3 \\
$\mathrm{Zn}_{3.0}$ & $85.10 \mathrm{a}$ & $122.5 \mathrm{a}$ & $120.7 \mathrm{a}$ & 109 & $11.57 \mathrm{a}$ & $38.13 \mathrm{a}$ & $37.83 \mathrm{a}$ & 29.2 \\
$\mathrm{Zn}_{4.0}$ & $79.1 \mathrm{ab}$ & $110.4 \mathrm{a}$ & $109.7 \mathrm{a}$ & 99.7 & $10.56 \mathrm{~b}$ & $34.45 \mathrm{~b}$ & $34.56 \mathrm{~b}$ & 26.5 \\
$\mathrm{CV}(\%)$ & 7.13 & 10.55 & 10.25 & - & 7.39 & 12.70 & 11.85 & - \\
\hline
\end{tabular}

Values within the same column with a common letter do not differ significantly $(\mathrm{p}=0.05)$

\section{Combined effect of $B$ and $\mathrm{Zn}$}

Yield contributing characters and yield of capsicum were affected significantly due to combined application of $\mathrm{Zn}$ and B fertilizer during 2010, 2011 and 2012 (Tables $6 \&$ 7). The highest number of fruits per plant, length and diameter of fruit were recorded from the combined treatment $\mathrm{B}_{2} \mathrm{Zn}_{3}$ which were significantly different with the other treatment, but some treatments $\left(T_{7}, T_{10}, T_{12}\right.$ and $\left.T_{15}\right)$ were showed identical and the lowest were recorded from treatment $\mathrm{B}_{0} \mathrm{Zn}_{0}$. Average number of fruits per plant, length and diameter of fruit were varied from 4.96 to $11.1,5.06$ to $9.29 \mathrm{~cm}$ and 4.10 to $7.34 \mathrm{~cm}$, respectively (Table 6). Hatwar et al. (2003) reported that application of micronutrients viz., zinc, iron and boron in combination, which resulted in improvement of growth, yield parameters of chilli. From the three years study it seems that the interaction effect showed narrower when either lowest or highest dose of zinc and boron was applied. Similar results were observed by Shil et al. (2013). 


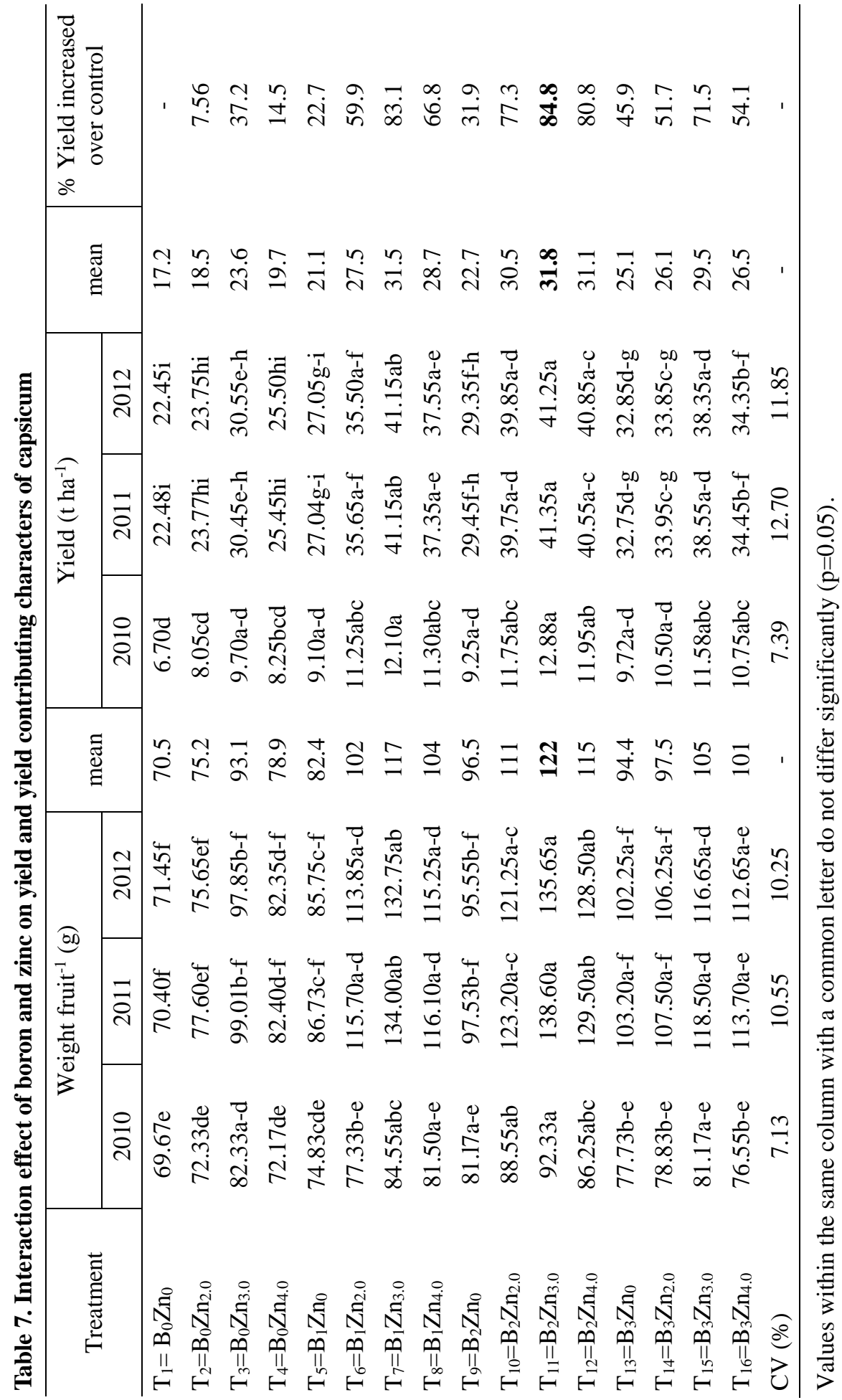


The highest fruit weight $(\mathrm{g})$ was found in the treatment $\mathrm{T}_{11}\left(\mathrm{~B}_{2} . \mathrm{Zn}_{3}\right)$ which was significantly higher with others treatment but statistically identical to $\mathrm{T}_{7}, \mathrm{~T}_{10}, \mathrm{~T}_{12}$ and $\mathrm{T}_{15}$ treatments. The average fruit weight ranged from 70.5 to $122 \mathrm{~g}$. The mean yield of capsicum was varied from 17.2 to $31.8 \mathrm{t} \mathrm{ha}^{-1}$ due to different treatment combinations. The highest yield was recorded from the treatment combination $\mathrm{T}_{11}\left(\mathrm{~B}_{2} . \mathrm{Zn}_{3}\right)$ which showed significantly different among the treatments but statistically identical with $\mathrm{T}_{6}, \mathrm{~T}_{7}, \mathrm{~T}_{8}, \mathrm{~T}_{10}, \mathrm{~T}_{12}$ and $\mathrm{T}_{15}$ treatments combination during 2010, 2011 and 2012. The lowest yield was obtained from control $\left(\mathrm{B}_{0} \mathrm{Zn}_{0}\right)$ treatment. The fruit yield increased over control ranged from 7.56 to $84.8 \%$ where the highest increase $(84.8 \%)$ was recorded from the treatment combination $\mathrm{T}_{11}\left(\mathrm{~B}_{2} \mathrm{Zn}_{3}\right)$ followed by $\mathrm{T}_{7}$ and $\mathrm{T}_{12}$ treatment. However, combined application of both boron and zinc was found to be more effective than their single application. Hatwar et al. (2003) reported application of micronutrients viz., zinc, iron and boron in combination, which resulted in improvement of yield parameters and yield of chilli. Quddus et al. (2014) observed that combined application of $\mathrm{Zn}$ and $\mathrm{B}$ significantly affected the yield and yield contributing characters of lentil. Sakal et al. (1986) also reported the similar trend.

Regression analysis showed positive and quadratic response for mean yield and applied B (Fig. 1). The optimum dose of B was calculated from the quadratic response function and was $2.97 \mathrm{~kg} \mathrm{ha}^{-1}$ (Table 8). For optimum dose, the maximum yield (29.31 t ha-1) could be expected in Gazipur area (Table 8). However, the optimum economic dose of $\mathrm{B}$ was $2.15 \mathrm{~kg} \mathrm{ha}^{-1}$. Beyond the optimum dose, $1 \mathrm{~kg} \mathrm{ha}^{-1}$ excess $\mathrm{B}$ was applied, then a risk of $7.65 \mathrm{t} \mathrm{ha}^{-1}$ reduced yield was noted (Table 8).

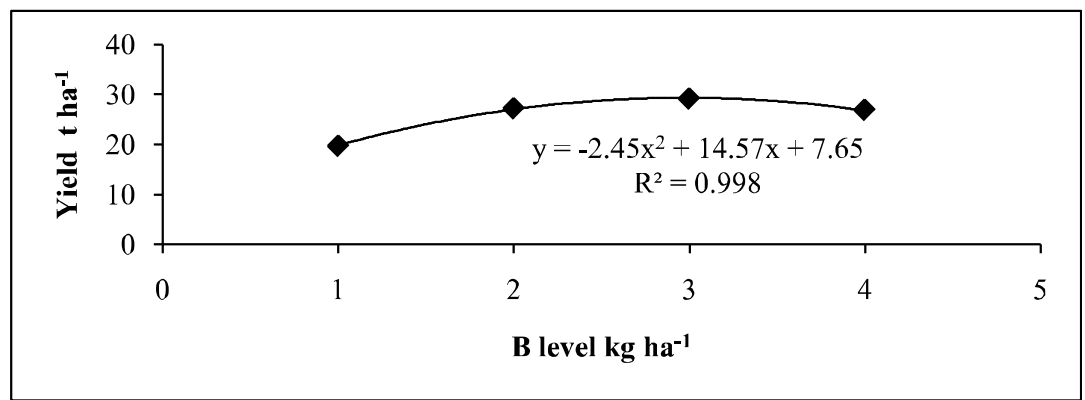

Fig. 1. Response of capsicum to boron fertilization.

A positive and quadratic relationship was also observed between yield and level of $\mathrm{Zn}$ (Fig. 2). The optimum dose of $\mathrm{Zn}$ from the quadratic production function was $2.98 \mathrm{~kg} \mathrm{ha}^{-1}$ (Table 8). Using the optimum dose, the maximum yield (28.66 t $\mathrm{ha}^{-1}$ ) could be expected for Gazipur area (Table 8). However, the optimum economic dose of $\mathrm{Zn}$ was $2.48 \mathrm{~kg} \mathrm{ha}^{-1}$. Above this optimum dose, $1 \mathrm{~kg} \mathrm{ha}^{-1}$ excess $\mathrm{Zn}$ if applied then there was a risk of $11.8 \mathrm{t} \mathrm{ha}^{-1}$ reduced yield (Table 8). 


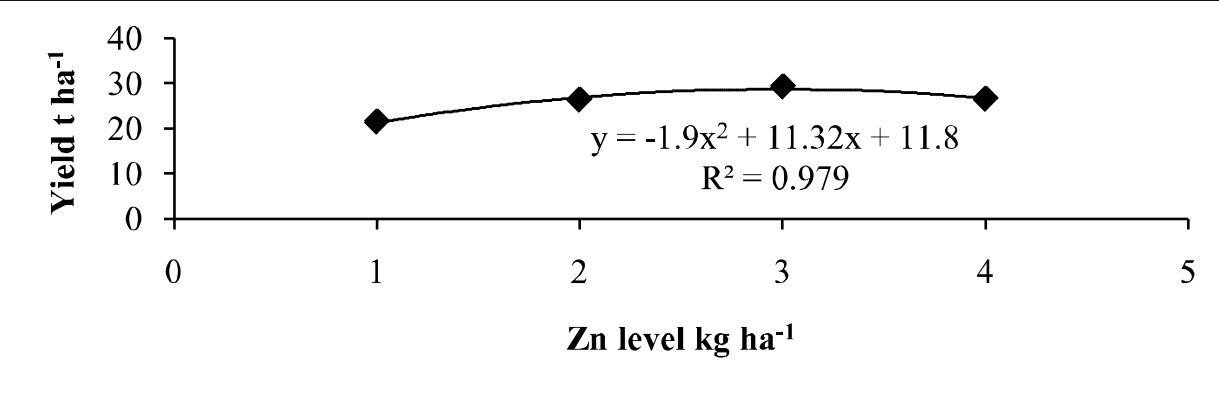

Fig. 2. Response of capsicum to zinc fertilization.

Table 8. Response function of capsicum to $\mathrm{B}$ and $\mathrm{Zn}$ for yield at Gazipur

\begin{tabular}{c|c|c|c|c|c}
\hline Regression equation & $\begin{array}{c}\text { Co-efficient } \\
\text { of } \\
\text { determination } \\
\left(\mathrm{R}^{2}\right)\end{array}$ & $\begin{array}{c}\text { Optimum } \\
\text { dose } \\
\left(\mathrm{kg} \mathrm{ha}^{-1}\right)\end{array}$ & $\begin{array}{c}\text { Economic } \\
\text { dose } \\
\left(\mathrm{kg} \mathrm{ha}^{-1}\right)\end{array}$ & $\begin{array}{c}\text { Maximum } \\
\text { yield }\left(\mathrm{t} \mathrm{ha} \mathrm{C}^{-1}\right) \\
\text { for optimum } \\
\text { dose }\end{array}$ & $\begin{array}{c}\text { Beyond optimum } \\
\text { dose the reduction } \\
\text { of yield }\left(\mathrm{t} \mathrm{ha}^{-1}\right) \text { for } \\
1 \mathrm{~kg} \mathrm{~B} \mathrm{or} \mathrm{Zn}\end{array}$ \\
\hline $\mathrm{B}$ & & & & & \\
$\mathrm{y}=\begin{array}{c}7.65+14.57 \mathrm{x}- \\
2.45 \mathrm{x}^{2}\end{array}$ & 0.998 & 2.97 & 2.15 & 29.31 & 7.65 \\
$\mathrm{Zn} \quad$ & & & & \\
$\mathrm{y}=\begin{array}{c}11.8+11.32 \mathrm{x}- \\
1.9 \mathrm{x}^{2}\end{array}$ & 0.979 & 2.98 & 2.48 & 28.66 & 11.8 \\
\hline
\end{tabular}

Capsicum $=200 \mathrm{Tk} . \mathrm{kg}^{-1} ; \mathrm{Zn}=377 \mathrm{Tk} . \mathrm{kg}^{-1} ; \mathrm{B}=800 \mathrm{Tk} . \mathrm{kg}^{-1}$.

\section{Conclusion}

From the trial, it could be concluded that combined application of boron and zinc at $2 \mathrm{~kg}$ and $3 \mathrm{~kg} \mathrm{ha}^{-1}$, respectively with blanket dose of $\mathrm{N}_{150} \mathrm{P}_{65} \mathrm{~K}_{120} \mathrm{~S}_{20} \mathrm{~kg} \mathrm{ha}^{-1}$ and cow dung $10 \mathrm{t} \mathrm{ha}^{-1}$ gives higher yield of capsicum in terrace soil under Madhupur Tract (AEZ 28). The quadratic response function, the optimum-economic dose of boron and zinc were calculated to be 2.15 and $2.48 \mathrm{~kg} \mathrm{ha}^{-1}$, respectively. So, the farmers of Gazipur can use $\mathrm{B}_{2.15} \mathrm{Zn}_{2.48} \mathrm{~kg} \mathrm{ha}^{-1}$ for capsicum cultivation.

\section{References}

Abdo, F.A. 2001. The response of two mungbean cultivars to zinc, manganese and boron1. Morphological, physiological and anatomical aspects. Bull. Fac. Agric. Cairo Uni. 52(3): 445-466.

AVRDC. 1989. Tomato and Pepper Production in the Tropics. AVRDC, Taiwan. P. 585.

Bakker, J. C. and J. A. M. Van Vffelum. 1987. The effects of diurnal temperature regimes on growth and yield of sweet pepper. Netherlands J. Agril. Sci. 36: 201-208.

Bhatt, R. M., N. K. Srubuvasa Rao and N. Anand. 1999. Response of bell pepper to irradiance photo synthesis, reproductive attributes and yield. Indian J. Hort. 56(1): 62-66. 
Dear, B.S. and J. Lipsett. 1987. The effect of boron supply on the growth and seed production of subterranean clover (Trifolium subterraneum L). Aust. J. Agric. Res. 38: 537-546.

Govindan, P. R. 1952. Influence of boron on yield and content of carbohydrates in tomato fruits. Curr. Sci. 21: 14-15.

Hasanuzzaman, S. M. 1999. Effect of hormone on yield of Bell pepper (C. annum). M. S. Thesis. Dept. of Hort. BAU, Mymensingh.

Hatwar, G. P., S. U. Gondane, S. M. Urkude, and O. V. Gahukar. 2003. Effect of micronutrients on growth and yield of chilli. J. Soil Crops 13: 123-125.

Hossain, M.A., M.A. Quddus and R.H. Mondol. 2010. Requirement of zinc for LentilMungbean-T.Aman rice cropping pattern in calcareous and non-calcareous soil. Annual Research Report, 2009-2010. Pulse Research Centre, BARI, Gazipur.

Islam, M.R., T.M. Riasat and M. Jahiruddin. 1997. Direct and residual effects of S, Zn and $\mathrm{B}$ on yield and nutrient uptake in a rice-mustard cropping system. J. Indian Soc. Soil Sci. 45: 126-129.

Jahiruddin, M., M.S. Haque, A.K.M.M. Haque and P.K. Ray. 1992. Influence of boron, copper and molybdenum on grain formation in wheat. Crop Res. 5: 35-42.

Knott, J. E. and J. R. Deanon. 1967. Eggplant, tomato and pepper. Vegetable production in South Asia, Laguna, Phillipines: University of Phillipines press. Pp. 99-109.

Manchanda, A. K. and B. Singh. 1987. Effect of plant density and nitrogen on yield and quality of bell pepper (Capsicum annum L.). Indian J. Hort. 44(3-4): 250-252.

Obata, H., S. Kawamura, K. Senoo and A. Tanaka. 1999. Changes in the level of protein and activity of $\mathrm{Cu} / \mathrm{Zn}$ superoxide dismutase in zinc deficient rice plant, Oryza sativa L. Soil Sci. Plant Nutr. 45: 891-896.

Quddus, M. A., M. H. Naser, M.A. Hossain and Abul M. Hossain. 2014. Effect of zinc and boron on yield and yield contributing characters of lentil in low ganges river floodplain soil at Madaripur, Bangladesh. Bangladesh J. Agril. Res. 39(4): 591-603.

Raj, S. 1985. An introduction to physiology of field crops, Oxford and IBH Publishing Co., New Delhi. Pp. 94-97.

Sakal, R., A. P. Singh and B. P. Singh. 1986. Annual report of all Indian coordinated scheme of micronutrients in soil and plants. RAU, Pusa, Bihar, India.

Warington, K. 1923. The effect of boric acid and borax on the broad bean and certain other plants. Ann. Bot. 40: 629-671. 